\title{
Peran Gaya Kepemimpinan dan Kompensasi dalam Mempengaruhi Kinerja yang Dimediasi oleh Kepuasan Kerja
}

\author{
Mirza Dwinanda Ilmawan', Dwi Setia Wulandari ${ }^{2}$, Fatmala Fitriani ${ }^{3}$ \\ Fakultas Ekonomi dan Bisnis Universitas Internasional Semen Indonesia
}

\begin{abstract}
The purpose of research to determine the influence of leadership style and compensation on employee performance through job satisfaction as intervening variable with quantitative approach conducted at head office of PT Varia Usaha, Gresik. Methods of data collection through questionnaires, research sample consists of 55 employees of the division of the Public Bureau at PT Varia Usaha, Gresik. Hypothesis testing uses linear regression analysis for hypotheses 1, 2, 3, 4 and 5, path analysis and double test for hypotheses 6 and 7. The results show that leadership style and job satisfaction have no effect on performance but there is influence between compensation with performance Employees. Leadership style and compensation have a positive effect on employee job satisfaction. The findings in this study that there is a positive and significant indirect influence between compensation on employee performance through job satisfaction. In addition, compensation has an indirect positive and significant impact on employee satisfaction mediated by job satisfaction.
\end{abstract}

Keywords: Leadership Style; Compensation; Job Satisfaction; Employee Performance

\begin{abstract}
Abstrak
Tujuan penelitian ini adalah untuk mengetahui pengaruh gaya kepemimpinan dan kompensasi terhadap kinerja karyawan melalui kepuasan kerja sebagai variabel intervening dengan pendekatan kuantitatif yang dilakukan di kantor pusat PT Varia Usaha, Gresik. Metode pengumpulan data melalui kuesioner, sampel penelitian terdiri dari 55 karyawan divisi Biro Umum pada PT Varia Usaha, Gresik. Pengujian hipotesis menggunakan analisis regresi linier untuk hipotesis 1,2, 3, 4 dan 5, analisis jalur dan uji sobel untuk hipotesis 6 dan 7. Hasil penelitian menunjukkan bahwa gaya kepemimpinan dan kepuasan kerja tidak berpengaruh terhadap kinerja namun terdapat pengaruh antara antara kompensasi dengan kinerja karyawan. Gaya kepemimpinan dan kompensasi berpengaruh positif terhadap kepuasan kerja karyawan. Temuan pada penelitian ini bahwa terdapat pengaruh tidak langsung yang positif dan signifikan antara kompensasi terhadap kinerja karyawan melalui kepuasan kerja. Selain itu, kompensasi berpengaruh tidak langsung positif dan signifikan terhadap kepuasan karyawan yang dimediasi oleh kepuasan kerja.
\end{abstract}

Kata Kunci: Gaya Kepemimpinan; Kompensasi; Kepuasan Kerja; Kinerja Karyawan

Permalink/DOI : http://dx.doi.org/10.21067/jem.v13i1.1762

Cara mengutip : Ilmawan, M., Wulandari, D., \& Fitriani, F. (2017). Peran Gaya Kepemimpinan dan Kompensasi dalam Mempengaruhi Kinerja yang Dimediasi oleh Kepuasan Kerja. Jurnal Ekonomi Modernisasi, 13(1), 37-45. doi:http://dx.doi.org/10.21067/jem.v13i1.1745

Sejarah Artikel : Artikel diterima : Januari 2017; direvisi Januari 2017; diterima Maret 2017

\footnotetext{
Alamat korespondensi :

Fakultas Ekonomi dan Bisnis Universitas Internasional Semen Indonesia Jl. Veteran, Komplek PT Semen Indonesia (Persero) Tbk.,Gresik, Jawa Timur

E-mail: mirza.ilmawan@uisi.ac.id 


\section{Pendahuluan}

Dunia kerja di Indonesia saat ini dituntut untuk mendapatkan sumber daya manusia yang unggul dan kompetitif dalam persaingan dunia usaha baik di tingkat nasional maupun internasional. Oleh karena itu, diperlukan tenaga kerja yang memiliki keahlian professional yang berkualitas untuk menghadapi perkembangan dan persaingan global baik masa kini maupun masa mendatang. Saat ini di Indonesia dihadapkan dengan era perdagangan bebas atau sering disebut Masyarakat Ekonomi Asia (MEA).

Perusahaan yang baik dapat terlihat dari keberhasilan mengelola sumber daya manusianya. Bagi perusahaan, mengelola sumber daya manusia bukan hal yang mudah karena melibatkan elemen di dalamnya, seperti karyawan, pemimpin, stakeholder serta sebuah sistem yang ada di dalam perusahaan. Sistem yang dimiliki oleh perusahaan tidak akan bermanfaat bagi perusahaan itu sendiri jika tidak didukung dengan sumber daya manusia yang baik. Terdapat beberapa hal yang dapat dilakukan oleh perusahaan untuk membentuk sumber daya manusia yang baik dan berkualitas serta sesuai dengan kebutuhan perusahaan yaitu memberikan kompensasi baik kompensasi langsung maupun tidak langsung, serta adanya gaya kepemimpinan yang baik sehingga berpengaruh terhadap kepuasan karyawan yang dapat mempengaruhi kinerja karyawan. Kinerja karyawan menurut Hasibuan (2009) mengemukakan kinerja (prestasi kerja) adalah suatu hasil kerja yang dicapai seseorang dalam melaksanakan tugas-tugas yang dibebankan kepadanya yang didasarkan atas kecakapan, pengalaman dan kesungguhan serta waktu. Kinerja karyawan harus dipantau dengan serius, karena memberikan dampak secara langsung terhadap perusahaan secara keseluruhan. Seperti yang diungkapkan Ilmawan dan Noermijati (2012) beberapa faktor yang dapat mempengaruhi kinerja di antaranya seperti gaya kepemimpinan, kompensasi, kepuasan kerja dan sebagainnya.

Hal yang harus diperhatikan adalah kepuasan kerja karyawan. Perusahaan harus menjamin karyawan puas dengan sesuatu yang diberikan oleh perusahaan, karena ketidakpuasan karyawan adalah menjadi titik awal munculnya sebuah masalah dalam perusahaan maupun sebuah organisasi seperti tingginya tingkat absensi, banyaknya turn over karyawan, masalah dengan atasan, bahkan mogok kerja. Menurut Hasibuan (2009) kepuasan kerja adalah sikap emosional yang menyenangkan dan mencintai pekerjaannya. Dalam dunia kerja, kepuasan itu salah satunya bisa mengacu kepada kompensasi yang diberikan pengusaha, termasuk gaji atau imbalan dan fasilitas kerja lainnya (Rivai, et. al., 2014). Notoatmodjo (2009) menyatakan bahwa kompensasi adalah segala sesuatu yang diterima oleh karyawan sebagai balas jasa untuk kerja atau pengabdian mereka. Kompensasi yang diberikan perusahan, baik kompensasi langsung maupun tidak langsung bertujuan untuk meningkatkan semangat dan kepuasan karyawan dalam bekerja guna mempertahankan karyawan dalam hal bentuk penghargaan oleh perusahaan kepada karyawan. Kepuasan dan kinerja karyawan juga dapat dipengaruhi oleh gaya kepemimpinan (Ilmawan dan Noermijati, 2012). Seorang pemimpin harus mampu beradaptasi dengan karyawan dan menerapkan strategi-strategi yang baik untuk menjalankan visi dan misi sebuah perusahaan. Rivai (2014) menerangkan bahwa gaya kepemimpinan merupakan pola perilaku dan strategi yang disukai dan sering 
Mirza Dwinanda Ilmawan, Dwi Setia Wulandari, Fatmala Fitriani/Peran Gaya Kepeminpinan...

diterapkan oleh seorang pemimpin dalam rangka mencapai sasaran organisasi.

Pada akhir Tahun 2016 PT Semen Indonesia (Persero) Tbk. menargetkan kapasitas produksi 38 juta ton, hal ini semakin mengokohkan posisi Semen Indonesia sebagai pemimpin pasar industri semen nasional, bahkan salah satu yang terbesar di Asia Tenggara. Kapasitas produksi dari PT Semen Indonesia yang semakin meningkat, tidak lepas dari peran anak usaha yaitu PT Varia Usaha sebagai roda penggerak distribusi di bidang transportasi, perdagangan dan manufaktur. Direktur Utama PT Varia Usaha, Faf Adisamsul disela pemberian penghargaan kesetiaan kerja di Wisma Ahmad Yani, menuturkan bahwa tahun ini PT Varia Usaha menargetkan pendapatan sebesar Rp. 6 triliun, atau tumbuh Rp. 1 triliun dibanding pendapatan Tahun 2015. Sejalan dengan pengembangan usaha tersebut, perusahaan yang memiliki visi menjadi perusahaan transportasi, perdagangan dan manufaktur berskala supply chain yang handal ini mulai menyiapkan SDM yang mendukung dengan melakukan pemberian sejumlah reward/kompensasi untuk menggenjot kinerja karyawan PT Varia Usaha.

Upaya untuk menjaga keberlangsungan kinerja yang baik merupakan tugas pemimpin untuk meningkatkan kinerja karyawan. Kompensasi juga merupakan faktor yang sangat penting bagi karyawan guna meningkatkan kinerja karyawan untuk meningkatkan poduktivitas. Tidak hanya itu, kompensasi juga memberikan kepuasan tersendiri kepada karyawan dengan cara bekerja lebih baik, minimnya kemangkiran, dan tingkat absensi yang rendah. Kepuasan kerja yang tinggi memberikan dampak positif terhadap karyawan seperti timbulnya loyalitas dan disiplin terhadap pekerjaan serta akan meningkatkan kinerja karyawan tersebut. Pemberian reward kepada karyawan bepengaruh terhadap kinerja karyawan. Banyak faktor dapat dilakukan oleh perusahaan untuk memperbaiki kinerja karyawan, seperti halnya gaya kepemimpinan yang harus diperbaiki. Hal tersebut berlawanan dengan temuan Juniarti (2014) yang mengemukakan bahwa kompensasi tidak berpengaruh signifikan terhadap kinerja karyawan perbankan bagian keuangan di Tanjung Pinang. Fenomena dan beberapa penelitian terdahulu di atas maka peneliti akan menambahkan kepuasan kerja sebagai variabel intervening untuk melihat pengaruhnya terhadap kinerja karyawan. Peran gaya kepemimpinan dan kompensasi dalam mempengaruhi kinerja yang dimediasi kepuasan kerja menjadi topik yang menarik untuk dikaji dalam penelitian ini. Studi akan dilakukan pada PT Varia Usaha, Gresik.

\section{Tinjauan Pustaka}

Nordhouse (2013) menjelaskan bahwa kepemimpinan terjadi di dalam kelompok di mana kelompok adalah konteks di mana kepemimpinan terjadi. Kepemimpinan termasuk aktivitas untuk mempengaruhi sekelompok manusia tersebut yang memiliki tujuan bersama. Konsep kekuasaan sangat penting untuk memahami bagaimana orang mampu saling mempengaruhi dalam organisasi (Yulk 2015). Yulk (2015) juga mengidentifikasikan bentuk kekuasaan yaitu reward power, coercive power, legitimate power, expert power dan refernt power. Menurut Nawawi (2003) ada dua dimensi kepemimpinan interaksisosial yang perlu diperhatikan oleh pimpinan adalah direction dan support.

Prasetiyo (2014) dalam studi yng dilakukan pada hotel berbintang di Yogyakarta menemukan pengaruh gaya 
kepemimpinan dan kompensasi terhadap kinerja karyawan dengan kepuasan kerja sebagai variabel intervening. Berdasarkan hasil penelitian diperoleh bahwa terdapat pengaruh positif dan signifikan gaya kepemimpinan terhadap Kepuasan Kerja. Notoatmodjo (2009) menyatakan bahwa kompensasi adalah segala sesuatu yang diterima oleh karyawan sebagai balas jasa untuk kerja atau pengabdian mereka.

Menurut Rivai (2014) terdapat dua jenis kompensasi yaitu kompensasi finansial dan kompensasi non finansial. Kompensasi finansial terdiri dari kompensasi tidak langsung dan langsung. Kompensasi langsung terdiri dari pembayaran karyawan dalam bentuk upah, gaji, bonus atau komisi. Kompensasi tidak langsung atau benefit terdiri dari semua pembayaran yang tidak tercakup dalam kompensasi finansial langsung yang meliputi liburan, berbagai macam asuransi, jasa seperti perawatan anak atau kepedulian keagamaan dan sebagainya. Penghargaan non finansial seperti pujian, menghargai diri sendiri dan pengakuan yang dapat mempengaruhi motivasi kerja karyawan, produktifitas dan kepuasan. Sedangkan menurut Simamora (2006) indikator-indikator kompensasi diantaranya upah dan gaji, insentif, tunjangan dan fasilitas.

Adapun Mangkunegara

menjelaskan kepuasan kerja adalah suatu perasaan yang menyokong atau tidak menyokong diri pegawai yang berhubungan dengan pekerjaannya maupun dengan kondisi dirinya. Menurut Hasibuan (2009) kepuasan kerja adalah sikap emosional yang menyenangkan dan mencintai pekerjaannya. Organisasi yang sukses dalam mencapai tujuannya, salah satunya karena organisasi tersebut mampu memenuhi kepuasan kerja karyawannya (Dharma dan Akib, 2005). Hasil kajian dari banyak penelitian juga menunjukkan adanya keyakinan yang kuat bahwa karyawan yang bahagia atau memiliki kepuasan kerja adalah karyawan yang produktif (Lawler Ill, 1973; Staw, 1991).

Secara teoritis Rivai (2014) menjelaskan faktor-faktor yang dapat mempengaruhi kepuasan kerja sangat banyak jumlahnya, seperti gaya kepemimpinan, produktifitas kerja, perilaku, locus of control, pemenuhan harapan penggajian dan efektifitas kerja. Namun faktor-faktor yang biasa digunakan untuk mengukur kepuasan kerja seorang karyawan adalah: (a) isi pekerjaan, penampilan tugas pekerjaan yang aktual dan sebagai kontrol terhadap pekerjaan; (b) supervisi; (c) organisasi dan manajemen; (d) kesempatan untuk maju; (e) gaji dan keuntungan dalam bidang finansial lainnya seperti adanya insentif; (f) rekan kerja; dan (g) kondisi pekerjaan. Selain itu menurut Job Descriptive Index (JDI) faktor penyebab kepuasan kerja ialah : (1) bekerja pada tempat yang tepat, (2) pembayaran yang sesuai, (3) organisasi dan manajemen, (4) supervisi pada pekerjaan yang tepat, dan (5) orang yang berada dalam pekerjaan yang tepat.

Ada beberapa indikator yang digunakan untuk mengetahui tingkat kepuasan kerja yang dirasakan oleh karyawan. Indikatorindikator kepuasan kerja menurut Marihot (2002) meliputi gaji, pekerjaan itu sendiri, rekan sekerja, atasan, promosi dan lingkungan kerja. Prasetyo (2014) dalam penelitiannya, "Pengaruh Gaya Kepemimpinan dan Kompensasi Terhadap Kinerja Karyawan dengan Kepuasan Kerja Sebagai Variabel Intervening" (Studi pada Hotel Berbintang di Yogyakarta) memperoleh bahwa terdapat pengaruh positif dan signifikan kompensasi terhadap kepuasan kerja.

Penelitian yang dilakukan Primanda dan Azzuhri (2014) yaitu "Pengaruh Motivasi Kerja Terhadap Kinerja Karyawan 
Mirza Dwinanda Ilmawan, Dwi Setia Wulandari, Fatmala Fitriani/Peran Gaya Kepeminpinan...

dengan Kepuasan Kerja Sebagai Variabel Intervening Pada Kantor Pusat PT Varia Usaha Gresik" diperoleh bahwa kepuasan kerja secara langsung memiliki pengaruh terhadap kinerja karyawan. Mangkunegara (2011) mengemukakan bahwa istilah kinerja berasal dari kata job performance atau actual performance yaitu hasil kerja secara kualitas dan kuantitas yang dicapai oleh seorang pegawai dalam melaksanakan tugasnya sesuai dengan tanggung jawab yang diberikan kepadanya. Prestasi pekerjaan atau kinerja yang diperoleh dapat dilihat dari perbandingan antara hasil kerja yang dapat dinilai dengan standar kerja dari organisasi tersebut.

Untuk mengetahui baik atau buruk kinerja seorang pegawai maka perlu dilakukan penilaian kinerja, yang pada dasarnya penilaian kinerja merupakan faktor kunci guna mengembangkan suatu organisasi secara efektif dan efisien. Penilaian kinerja adalah proses dimana organisasi mengawasi pelaksanaan kerja individu karyawan (Simamora, 2006). Menurut Dessler (2015) ada lima faktor dalam penilaian kinerja yaitu kualitas pekerjaan, kuantitas pekerjaan, supervisi yang diperlukan, kehadiran dan konservasi dalam melakukan penilaian kinerja pegawai. Diperlukan langkah-langkah berikut untuk melakukan penilaian kinerja (Dessler, 2015): (a). Mendefinisikan pekerjaan, yang berarti memastikan bahwa atasan dan bawahan sepakat tentang tugas-tugasnya dan standar jabatan. (b). Menilai kinerja, berarti membandingkan kinerja aktual bawahan dengan standar yang telah ditetapkan dan ini mencakup beberapa jenis tingkat penilaian. (c). Sesi umpan balik, berarti kinerja dan kemajuan bawahan dibahas dan rencanarencana dibuat untuk perkembangan apa saja yang dituntut

Adapun faktor-faktor yang mempengaruhi kinerja menurut Riani (2011) yaitu: (a). Kemampuan, kepribadian dan minat kerja, (b). Kejelasan dan penerimaan atau penjelas peran seorang pekerja yang merupakan taraf pengertian dan penerimaan seseorang atas tugas yang diberikan kepadanya. (c). Tingkat motivasi pekerja yaitu daya energi yang mendorong mengerahkan dan mempertahankan perilaku.

\section{Metode}

Jenis penelitian ini merupakan penelitian survei, di mana penelitian ini mengambil sampel dari suatu populasi dan menggunakan kuesioner sebagai instrumen pengumpulan data yang utama. Penelitian ini dikategorikan sebagai explanatory research, yaitu penelitian yang menjelaskan hubungan kausal antara variabel-variabel penelitian melalui pengujian hipotesis (Singarimbun dan Effendi, 2006). Lingkungan penelitiannya menggunakan penelitian lapangan yang bertujuan untuk mendapatkan data empiris untuk pengujian hipotesis. Penelitian ini dilakukan di Biro Umum PT Varia Usaha, Gresik, Jawa Timur. Penelitian ini dilaksanakan pada Tahun 2016.

Sanusi (2003) menyatakan untuk penelitian yang sifatnya menguji hubungan antara dua variabel atau lebih (penelitian kolerasional) minimal diambil 30 sampel. Bila populasi besar dan peneliti tidak memungkinkan untuk mempelajari semua yang ada pada populasi, misalnya karena keterbatasan dana, tenaga, dan waktu, maka peneliti dapat menggunakan sampel yang diambil dari populasi itu. Seperti yang diungkapkan oleh Sanusi (2003) bahwa tidak ada seorang pakar atau ahli yang dapat menyatakan berapa ukuran sampel (jumlah sampel) secara tepat yang seharusnya digunakan dalam penelitian. 
Obyek dan subyek penelitian ini adalah karyawan PT Varia yang berada di pusat perusahaan yang berada di Kota Gresik.

Teknik pengumpulan data primer dilakukan dengan memberikan daftar pernyataan tertulis kepada responden untuk dijawab melalui instrumen berupa kuesioner. Kuesioner dikembangkan dengan memasukan berbagai indikator-indikator dari berbagai variabel dalam model empirik, yang diperoleh dari telaah literatur dan hasil penelitian. Kuesioner berisi pernyataan tertutup dan pertanyaan terbuka. Pertanyaan terbuka disertakan untuk memperjelas jawaban yang diperoleh dari pernyataan tertutup. Sedangkan teknik pengumpulan data sekunder dilakukan melalui dokumentasi, dalam hal ini dari intern sekolah, surat kabar, buku dan jurnal yang menunjang penelitian ini. Dalam penelitian ini peneliti menggunakan cara questionare (angket) sebagai teknik untuk mendapatkan sebuah data dari responden.

\section{Hasil dan Pembahasan}

Deskripsi kategori variabel ini menjawab dari tanggapan para responden mengenai pengaruh gaya kepemimpinan dan kompensasi terhadap kinerja karyawan dengan kepuasan kerja sebagai variabel intervening. Pada penelitian ini jawaban responden dikategorikan dalam lima kategori dengan menggunakan skala Likert. Masing-masing skala penilaian dari sangat rendah ke sangat tinggi yang dituangkan dalam pilihan jawaban kuesioner. Dalam memberikan interpretasi nilai rata-rata atau pemberian makna penilaian secara empiris variabel penelitian ini mengadopsi dasar interpretasi yang digunakan dalam penelitian Noermijati (2008) dengan rata-rata pembobotan atau skor jawaban responden yang diperoleh dengan mengklasifikasikan ke dalam rentang skala kategori nilai dari nilai sangat rendah sampai dengan sangat tinggi.

\section{Gaya Kepemimpinan}

Gaya kepemimpinan yang diberikan kepada karyawan berada pada kategori tinggi yang ditunjukan dengan nilai mean atau nilai rata-rata variabel Gaya Kepemimpinan sebesar 3.798. Hal ini menggambarkan bahwa gaya kepemimpinan dari atasan sudah sesuai yang diinginkan atau yang diharapkan oleh karyawan. Untuk nilai ratarata setiap indikator dari variabel Gaya Kepemimpinan, skor tertinggi adalah pada indikator kepemimpinan direktif. Tetapi di dalam indikator tersebut ada tiga pertanyaan negatif, sehingga dapat dikatakan bahwa kepemimpinan direktif bernilai sangat rendah, yang artinya karyawan tidak setuju jika atasan mereka tidak mau menerima saran dan masukkan dari karyawan, atasan mengambil keputusan tanpa konsultasi dengan karyawan dan atasan bersifsat tertutup. Pada indikator kepemimpinan suportif memiliki nilai mean atau rata-rata yang tinggi yakni sebesar 3,6 yang artinya karyawan setuju bahwa atasan mereka memiliki gaya kepemimpinan yang suportif seperti mendorong karyawan untuk bekerja dengan semangat dan meminta karyawan untuk mengerjakan tugas dengan sebaikbaiknya. Sama halnya dengan indikator kepemimpinan partisipatif memiliki nilai mean atau rata-rata sebesar 3,7 yang artinya karyawan menilai bahwa atasan mereka memiliki gaya kepemimpinan partisipatif seperti selalu terbuka dalam menerima kritik dan saran dan memberikan informasi terbaru untuk karyawan.

\section{Kompensasi}

Nilai rata-rata dari variabel karakteristik kompensasi sebesar 3.5422 dan termasuk dalam kategori tinggi. Hal ini 
Mirza Dwinanda Ilmawan, Dwi Setia Wulandari, Fatmala Fitriani/Peran Gaya Kepeminpinan...

menggambarkan bahwa responden berpendapat bahwa karakteristik kepuasan dari perusahaan sudah sesuai dengan keinginan atau kebutuhan karyawan Sedangkan nilai rata-rata tertinggi dari setiap indikator dihasilkan dari indikator $\mathrm{X}_{1.4}$ yakni indikator fasilitas yang diberikan oleh perusahaan yang memiliki nilai rata-rata sebesar 3,812. Dapat dilihat bahwa responden sangat memperhatikan item karakter fasilitas kerja seperti seragam secara gratis.

\section{Kepuasan Kerja}

Nilai rata-rata variabel kepuasan kerja sebesar 3.4994 dapat dikategorikan tinggi. Responden sangat menyukai pekerjaan, rekan kerja, lingkungan kerja, gaji dan atasan yang ada saat ini. Hal ini sejalan dengan apa yang telah dibahas pada penjelasan tentang karakteristik responden yang membuktikan bahwa sebagian besar responden telah bekerja dengan rentang masa kerja lebih dari 15 tahun, dan meskipun kebanyakan di perusahaan rata-rata adalah karyawan baru yakni dengan masa kerja selama 1 sampai 5 tahun yakni sebanyak 25 responden. Mereka menyukai pekerjaan yang dilakukan saat ini dan berkeinginan kuat untuk tetap menjadi karyawan hingga sekarang.

\section{Kinerja Karyawan}

Data kinerja Karyawan telah dikombinasikan dengan jawaban atas kinerja responden oleh atasan. Kinerja Karyawan dapat diukur dengan tiga indikator kompetensi yaitu kualitas kerja karyawan, Kuantitas kerja karyawan, dan Ketetapan. Nilai rata-rata variabel kinerja karyawan yang tergolong tinggi yaitu sebesar 3.628. Nilai rata-rata indikator tertinggi diperoleh dari indikator ketepatan waktu sebesar 3.8075 .
Hasil uji validitas dari seluruh instrumen memiliki koefisien korelasi $\geq 0.30$ sehingga dapat disimpulkan bahwa semua item pernyataan yang digunakan sebagai instrumen dalam penelitian ini adalah valid dan layak untuk dianalisis lebih lanjut. Nilai Alpha Cronbach's dari seluruh indikator variabel yang dijadikan sebagain intrumen dalam penelitian ini adalah masih berada di atas cut of value $\geq 0.6$ berarti semua item pernyataan yang dijadikan instrumen dapat dipercaya keandalanya. Persyaratan nilai alpha cronbach's telah terpenuhi oleh semua indikator variabel dengan nilai berada diatas 0.6 atau 60\% sehingga instrumen layak untuk dianalisis lebih lanjut.

\section{Perhitungan Koefisien Jalur}

Variabel laten yang dibangun dalam penelitian ini yaitu kompensasi, karakteristik kepemimpinan, kepuasan karyawan, dan kinerja karyawan. Selanjutnya keempat variabel laten dalam penelitian ini dihubungkan sehingga menghasilkan tujuh jalur dalam model penelitian ini yaitu lima pengaruh langsung dan dua pengaruh tidak langsung.

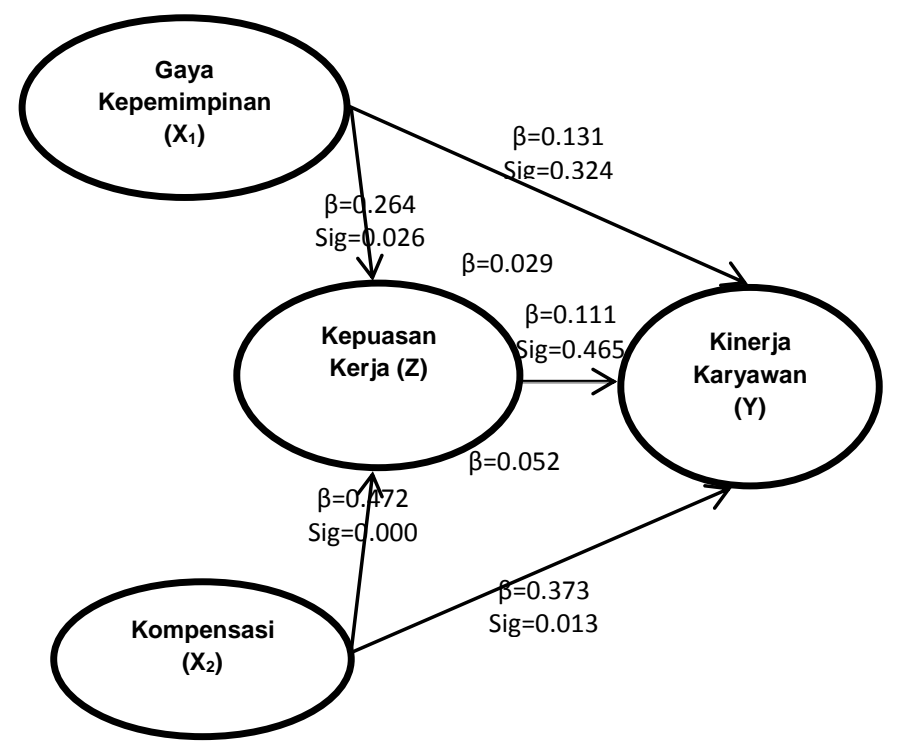

Gambar 1 Hasil pengujian path analysis 
Data mengenai besarnya dan tingkat signifikansi kelima pengaruh langsung antar variabel yang diteliti dalam penelitian ini dapat dilihat pada Tabel 8 berikut:

Tabel 1. Standardized Regression Weightsantar Variabel Laten Penelitian

\begin{tabular}{llllll}
\hline Variabel Terikat & Variabel Bebas & $\begin{array}{l}\text { Koef. } \\
\text { Beta }\end{array}$ & $\mathrm{t}$ & Sig & Keterangan \\
\hline Gaya Kepemimpinan & Kepuasan Kerja $(\mathrm{Z})$ & .264 & 2.294 & .026 & Signifikan \\
\hline Kompensasi & Kepuasan Kerja $(\mathrm{Z})$ & .472 & 4.104 & .000 & Signifikan \\
\hline Gaya Kepemimpinan & Kinerja Karyawan(Y) & .131 & 0.996 & .324 & Tidak Signifikan \\
\hline Kompensasi & Kinerja Kinerja (Y) & .373 & 2.587 & .013 & Signifikan \\
\hline Kepuasan Kerja & Kinerja Karyawan (Y) & .111 & 0.736 & .465 & Tidak Signifikan \\
\hline Sumber: Data primer diolah 2016 & & & &
\end{tabular}

Tabel 2 Standardized Direct, Inderect, dan Total Effectantar Variabel Laten

\begin{tabular}{lccc}
\hline Pengaruh Antar Variabel Laten & Langsung & Tidak Langsung \\
\hline Kinerja Karyawan $\leftarrow$ Kepuasan Kerja $\leftarrow \begin{array}{l}\text { Gaya } \\
\text { Kepemimpinan }\end{array}$ & 0.131 & 0.029 \\
\hline Kinerja Karyawan $\leftarrow$ & Kepuasan Kerja $\leftarrow$ Kompensasi & 0.373 & 0.052 \\
\hline
\end{tabular}

Sumber: Data primer diolah 2016

Selain itu terdapat dua indikator validitas model di dalam analisis jalur, yaitu koefisien determinasi total dan trimming theory.

Koefisien Determinasi Total

Total keragaman data yang dapat dijelaskan oleh model diukur dengan:

$$
\mathrm{R}_{\mathrm{m}}^{2}=1-\mathrm{P}_{\mathrm{e} 1}^{2} \mathrm{P}_{\mathrm{e} 2 \ldots}^{2} \ldots \mathrm{P}_{\mathrm{ep} n}^{2}
$$

Interpretasi terhadap $\mathrm{R}_{\mathrm{m}}^{2}$ sama dengan interpretasi koefisien determinasi $\left(\mathrm{R}^{2}\right)$ pada analisis regresi. Model dikatakan valid jika memiliki presisi dan akurasi tinggi.Ukuran akurasi model adalah koefisien determinasi $\left(\mathrm{R}^{2}\right)$ dengan nilai berkisar dari 0 sampai dengan 1. Berdasarkan Gambar 1 diperoleh koefisien determinasi total:

$$
\begin{aligned}
& \mathrm{Pe}_{1}=\sqrt{1-R_{1}^{2}} \\
& \mathrm{Pe}_{2}=\sqrt{1-R_{2}^{2}} \\
& \mathrm{Pe}_{1}=\sqrt{1-0.354} \\
& \mathrm{Pe}_{2}=\sqrt{1-0.249} \\
& \mathrm{Pe}_{1}=0.803 \\
& \mathrm{Pe}_{2}=0.866
\end{aligned}
$$

$$
\begin{aligned}
\mathrm{R}^{2}{ }_{\mathrm{m}} & =1-\mathrm{P}_{\mathrm{e} 1}^{2} \mathrm{P}_{\mathrm{e} 2 \ldots . . . \mathrm{P}^{2}{ }_{\mathrm{ep} n}} \\
\mathrm{R}^{2}{ }_{\mathrm{m}} & =1-(0.803)^{2}(0.866)^{2} \\
& =1-(0.645)(0.750) \\
& =0.516 \\
& =51.6 \%
\end{aligned}
$$

Nilai $\mathrm{R}_{\mathrm{m}}{ }_{\mathrm{m}}$ tersebut menunjukkan informasi yang terkandung dalam data $51.6 \%$ dapat dijelaskan oleh model. Sedangkan sisanya $48.4 \%$ dijelaskan oleh variabel lain yang belum terdapat dalam model dan error. Koefisisn $\mathrm{R}^{2}{ }_{\mathrm{m}}$ sebesar $51.6 \%$ dikategorikan sangat tinggi, sehingga model dikatakan sangat baik. Model dengan koefisien determinasi total yang besar menunjukkan model yang semakin baik.

\section{Triming Theory}

Berdasarkan trimingtheory dengan menggunakan $\alpha=0.05$, maka jalur-jalur yang nonsignifikan dibuang, sehingga diperoleh model yang didukung oleh data empirik. Pada penelitian ini semua lintasan atau hubungan yang dibentuk berpengaruh 
signifikan, sehingga diperoleh model baik yang sesuai dengan teori dan penelitian terdahulu.

Berdasarkan hasil uji hipotesis dapat diketahui seluruh variabel independen berpengaruh positif dan signifikan terhadap variabel dependen. Variabel gaya kepemimpinan dan kompensasi memiliki peran yang lebih baik untuk meningkatkan kepuasan kerja dari karyawan dimana kepuasan kerja dalam penelitian ini berperan sebagai variable intervening. Variabel kepuasan kerja merupakan variabel yang tidak mempengaruhi variabel kinerja karyawan .Berikut ini disajikan pembahasan hasil penelitian yang didasarkan pada hasil pengujian hipotesis yang dikemukakan dalam model penelitian dan dukungan teori dan hasil-hasil penelitian terdahulu.

\section{Pengaruh Gaya Kepemimpinan Terhadap Kepuasan Kerja}

Hasil penelitian ini menunjukkan bahwa Gaya kepemimpinan berpengaruh signifikan dan positif terhadap kepuasan kerja. Hal tersebut berarti gaya kepemimpinan atasan akan berdampak secara langsung meningkatkan kepuasan kerja dari para karyawan. Hal ini sesuai dengan pernyataan Prasetiyo (2014) yang menyatakan bahwa terdapat pengaruh positif dan signifikan gaya Kepemimpinan terhadap kepuasan Kerja. Responden bersikap positif terhadap gaya kepemimpinan di lingkungan pekerjaan mereka. Artinya mereka merasa puas terhadap gaya kepemimpinan.

Hasil analisis deskriptif menunjukkan bahwa gaya kepemimpinan yang berada di PT Varia Usaha pada kategori tinggi yang ditunjukan dengan nilai mean atau nilai ratarata variabel sebesar 3.789. Untuk nilai ratarata setiap indikator dari variabel gaya kepemimpinan, skor tertinggi adalah pada indikator kepemimpinan partisipatif dimana atasan selalu terbuka dalam menerima kritik dan saran dengan nilai rata-rata 3.85. kemudian indikator kepemimpinan direktif memiliki nilai rata-rata 4.04 dimana atasan menjalankan peraturan dengan tegas. Namun untuk nilai rata-rata tertinggi dari setiap item, skor tertinggi dicapai oleh salah satu item dari indikator kepemimpinan suportif. Item ini berkenaan dengan atasan memperlakukan semua karyawan dengan sama. Responden dengan yakin menganggap atasan memperlakukan semua karyawan dengan sama hal ini dapat dibuktikan dengan nilai rata-rata 4.11. Hal tersebut dibuktikan oleh sikap responden yang sangat menyukai gaya kepemimpinan atasan mereka dengan nilai rata-rata tertinggi dibanding indikator lain.

Deskriptif tersebut dapat dilihat bahwa responden menganggap bahwa gaya kepemimpinan yang dilakukan atasan kepada karyawan akan berbanding lurus dengan kepuasan kerja dari para karyawan yang positif dan signifikan, sehingga dapat dikatakan gaya kepemimpinan yang dilakukan oleh atasan kepada karyawan dapat meningkatkan kepuasan kerja dari para karyawan. Dalam observasi yang dilakukan oleh penulis, karyawan merasa puas dengan gaya kepemimpinan, karena dapat mengontrol dan mengevaluasi karyawan dalam menjalankan tugas. Tidak hanya itu, melainkan gaya kepemimpinan seorang pemimpin dapat membantu menyelesaikan sebuah masalah yang telah dilakukan oleh bawahan.

\section{Pengaruh Kompensasi terhadap Kepuasan kerja}

Hasil penelitian ini menunjukkan bahwa karakteristik kompensasi berpengaruh signifikan dan positif terhadap kepuasan kerja. Hal tersebut berarti semakin besar kompensasi yang diberikan akan berdampak secara langsung dalam 
Mirza Dwinanda Ilmawan, Dwi Setia Wulandari, Fatmala Fitriani/Peran Gaya Kepeminpinan...

meningkatkan kepuasan kerja para karyawan.

Pada penelitian ini, kompensasi dinilai dari beberapa indikator seperti upah dan gaji, insentif, tunjangan, fasilitas .Dari hasil analisis deskriptif data dapat diketahui bahwa kompensasi di PT Varia Usaha pada kategori tinggi yang ditunjukan dengan nilai mean atau nilai rata-rata variabel sebesar 3.5422. Untuk nilai rata-rata setiap indikator dari variabel kompensasi, skor tertinggi adalah pada indikator insentif dimana jika bekerja dengan baik maka akan mendapatkan bonus dengan nilai rata-rata 3.36. kemudian indikator tunjangan memiliki nilai rata-rata 3,84 dimana perusahaan memberikan tunjangan asuransi sebagai tanggung jawab keselamatan kerja karyawan. Untuk indikator berikutnya upah dan gaji dengan nilai rata-rata 3.96 dimana gaji atau upah yang diterima tepat waktu sesuai harapan. Responden dengan yakin menganggap bahwa fasilitas yang telah mereka dapatkan telah sesuai dengan harapan mereka, dibuktikan dengan nilai rata-rata tertinggi dari setiap item, skor tertinggi dicapai oleh indikator fasilitas sebesar 4.25. Item ini berkenaan dengan perusahaan memberikan fasilitas kerja seragam kerja secara gratis. Hal tersebut dibuktikan oleh sikap responden yang sangat menyukai pekerjaan mereka yang dilakukan saat ini dengan nilai rata-rata tertinggi dibanding indikator lain Hasil penelitian ini mendukung hasil penelitian Prasetiyo (2014) yang meneliti tentang Pengaruh gaya kepemimpinan dan kompensasi terhadap kinerja karyawan dengan kepuasan kerja sebagai variabel intervening (Studi pada Hotel Berbintang di Yogyakarta). Hasil dari penelitian tersebut menyatakan bahwa terdapat hubungan dan pengaruh signifikan antara variabel kompensasi dengan kepuasan kerja karyawan.

\section{Pengaruh Kepuasan terhadap Kinerja Karyawan}

Hasil penelitian ini menunjukkan bahwa kepuasan tidak berpengaruh signifikan dan positif terhadap kinerja karyawan. Hal tersebut berarti semakin baik kepuasan kerja yang dirasakan oleh karyawan maka akan berdampak secara langsung dalam meningkatkan kinerja karyawan.

Dalam penelitian ini, kepuasan dinilai dari beberapa indikator seperti pekerjaan itu sendiri, kondisi lingkungan kerja, rekan kerja, gaji, atasan, promosi. Dari hasil analisis deskriptif data dapat diketahui bahwa kepuasan di PT Varia Usaha pada kategori tinggi yang ditunjukan dengan nilai mean atau nilai rata-rata variabel sebesar 3.4994. Hasil analisis deskriptif untuk nilai rata-rata setiap indikator dari variabel kepuasan, skor tertinggi adalah pada indikator kondisi lingkungan kerja dimana kondisi penerangan diruang kerja dengan nilai rata-rata 3.82. Nilai rata-rata tertinggi diperoleh dari indikator rekan kerja dimana hubungan baik antar rekan kerja. Responden dengan yakin menganggap bahwa kepuasan kerja dilihat dari sikap saling mendukung serta kerjasama antar karyawan dalam menyelesaikan setiap pekerjaan yang dapat dibuktikan dengan nilai rata-rata 3.84 .

Hasil dalam penelitian ini tidak mendukung Primanda dan Azzuhri (2014) yaitu pada penelitian Pengaruh Motivasi Kerja Terhadap Kinerja Karyawan Dengan Kepuasan Kerja Sebagai Variabel Intervening pada Kantor Pusat PT Varia Usaha Gresik yang menemukan bahwa sistem kepuasan kerja secara langsung memiliki pengaruh terhadap kinerja karyawan. Tidak selaras karena sesuai dengan observasi yaitu adanya perpindahan rekan kerja, dan atasan. Ketika peneliti di perusahaan adanya pergantian atasan, dan 
adanya karyawan baru, sehingga karyawan (bawahan) harus beradaptasi dengan tim kerja yang berada dalam biro tersebut. Sehingga kepuasan tidak signifikan dengan kinerja. Mereka puas dengan pekerjaan yang mereka lakukan dan menerima segala pergantian, tetapi tidak ada hubungan dengan kinerja. Karyawan merasa akan melaksanakan pekerjaan sebaik mungkin.

\section{Pengaruh Gaya Kepemimpinan terhadap Kinerja Karyawan}

Hasil penelitian ini menunjukkan bahwa gaya kepemimpinan tidak berpengaruh signifikan dan positif terhadap kinerja karyawan. Hal tersebut berarti model gaya kepemimpinan yang diberikan kepada karyawan tidak akan berdampak secara langsung meningkatkan kinerja karyawan. Responden merasa gaya kepemimpinan adalah segala sesuatu bentuk dorongan dan sikap yang mereka terima dari atasan sebagai motivasi pekerjaannya, namun apapun bentuk dorongan dan sikap yang diberikan atasan tidak berpengaruh langsung terhadap kinerja karyawan. Karyawan akan menyelesaikan tugas tepat waktu karena pekerjaan yang mereka lakukan setiap hari sama dan tidak ada yang berbeda. Berdasarkan hasil observasi di perusahaan, banyak hal yang menyebabkan gaya kepemimpinan tidak berpengaruh langsung dengan kinerja karyawan yaitu, karena seringnya pemimpin dalam biro tersebut keluar ruangan, serta seringnya pemimpin keluar kota, karena PT. Varia Usaha mempunyai unit area yang tersebar di Jawa Timur, Jawa Tengah, dan Jawa Barat. Pemimpin juga terkadang menemui supplier untuk bekerjasama dengan perusahaan. Sehingga gaya kepemimpinan yang telah dibentuk oleh pemimpin dan perusahaan tidak berpengaruh langsung dengan kinerja karyawan. Kinerja karyawan sangat dilakukan dengan baik walaupun terkadang pekerjaan yang memerlukan campur tangan pemimpin sering menunggu pemimpin untuk selalu ada diruangan tersebut. Secara garis besar gaya kepemimpinan hanya dibutuhkan saat tim benar-benar memerlukan campur tangan untuk menyelesaikan masalah yang sangat besar. Selain itu, karyawan mampu melaksanakan kinerja sehari-hari dengan baik tanpa campur tangan pemimpin, karena perusahaan sudah memiliki tekhnologi yang sangat baik, hanya dengan menggunakan software karyawan dapat meningkatkan kinerjanya dan menyelesaikan tugasnya dengan baik.

Hasil analisis deskriptif untuk nilai rata-rata setiap indikator dari variabel gaya kepemimpinan, skor tertinggi adalah pada indikator kepemimpinan direktif dimana atasan memberikan kesempatan kepada karyawan untuk memberikan saran dan bersikap terbuka kepada karyawan dengan nilai 3.89. karyawan merasa atasan sangat terbuka dalam hal saran serta sudah baik dalam menjalankan peraturan yang dibuat oleh perusahaan. kemudian indikator kepemimpinan direktif memiliki nilai ratarata 4.04 dimana atasan menjalankan peraturan dengan tegas. Namun untuk nilai rata-rata tertinggi dari setiap item, skor tertinggi dicapai oleh salah satu item dari indikator kepemimpinan suportif. Item ini berkenaan dengan atasan memperlakukan semua karyawan dengan sama. Responden dengan yakin menganggap atasan memperlakukan semua karyawan dengan sama hal ini dapat dibuktikan dengan nilai rata-rata 4.11. Hal tersebut dibuktikan oleh sikap responden yang sangat menyukai gaya kepemimpinan atasan mereka dengan nilai rata-rata tertinggi dibanding indikator lain. 
Mirza Dwinanda Ilmawan, Dwi Setia Wulandari, Fatmala Fitriani/Peran Gaya Kepeminpinan...

\section{Pengaruh Kompensasi terhadap Kinerja Karyawan}

Hasil penelitian ini menunjukkan bahwa kompensasi berpengaruh signifikan dan positif terhadap kinerja karyawan. Hal tersebut berarti peningkatan besaran kompensasi yang diberikan kepada karyawan maka akan berdampak secara langsung meningkatkan kinerja karyawan. Responden merasa kompensasi adalah segala sesuatu yang mereka terima sebagai kontribusi balas jasa atas kerja mereka dan merupakan salah satu upaya untuk meningkatkan kinerja mereka.

Hasil analisis deskriptif untuk nilai rata-rata setiap indikator dari variabel kompensasi, skor tertinggi adalah pada indikator upah dan gaji dengan nilai rata-rata 3.695. Hal ini ditunjukkan oleh gaji atau upah yang diberikan oleh perusahaan tepat waktu dan sesuai dengan kinerja karyawan, besarnya gaji apakah sudah sesuai dengan tugas dan tanggung jawab sebagai karyawan. Responden meyakini bahwa gaji mereka telah sesuai dengan tanggung jawab dan tugas yang telah mereka kerjakan. Adapun nilai rata-rata tertinggi dicapai oleh salah satu item dari indikator fasilitas yakni sebesar 3.812. Item ini berkenaan dengan fasilitas yang diberikan oleh perusahaan menjadi salah satu alasan karyawan untuk meningkatkan kinerja karyawan. Hasil dalam penelitian ini mendukung penelitian Primanda dan Azzuhri (2014) juga mengemukakan bahwa terdapat pengaruh langsung dan signifikan antara variabel kompensasi finansial terhadap kinerja karyawan. Artinya apabila seseorang akan bekerja keras dan semakin rajin, jika mereka terus menerus mendapat kompensasi yang diberikan secara layak dan cukup maka kinerja akan meningkat.

\section{Pengaruh Gaya Kepemimpinan terhadap Kinerja Karyawan melalui Kepuasan Kerja}

Hasil penelitian ini menunjukkan adanya pengaruh positif dan signifikan tidak langsung antara kompensasi terhadap kinerja karyawan melalui kepuasan kerja. Hal tersebut berarti semakin baik Kepemimpinan yang diberikan kepada karyawan maka akan dapat meningkatkan kepuasan dari karyawan tetapi jika pengaruh gaya kepemimpinan terhadap kinerja karyawan melalui kepuasan maka tidak signifikan karena karyawan sudah merasa puas terhadap apapun yang dilakukan pemimpin dan tidak berpengaruh lagsung terhadap kinerjanya, karena karyawan sudah merasa kinerja merupakan kewajiban sebagai karyawan, jadi karyawan akan melaksanakan kinerjanya dengan baik karena mereka puas terhadap perusahaan tersebut.

\section{Pengaruh Kompensasi terhadap Kinerja Karyawan melalui Kepuasan Kerja}

Hasil penelitian ini menunjukkan adanya pengaruh positif dan signifikan tidak langsung kompensasi terhadap kepuasan karyawan yang dimediasi oleh kepuasan kerja. Hal tersebut berarti semakin baik kompensasi yang diberikan oleh perusahaan maka akan meningkatkan kepuasan kerja dari karyawan, tetapi dalam hal kepuasan tidak ada soal dalam kepuasan yang menyangkut mengenai kinerja yang pada akhirnya akan tidak berdampak secara tidak langsung meningkatkan kinerja karyawan. Penelitian ini mendukung hasil dari Aryo Primanda dan Azzuhri (2014) yang menemukan bahwa sistem kompensasi berpengaruh positif dan signifikan secara langsung maupun tidak langsung pada kinerja karyawan. 
Hasil penelitian ini menunjukkan bahwa tidak terdapat kesamaan dengan hasil penelitian terdahulu berkenaan dengan hubungan Gaya Kepemimpinan terhadap Kinerja karyawan. Hasil penelitian ini tidak sama dengan penelitian yang dilakukan Hendriawan (2014) yang meneliti tentang gaya kepemimpinan pengaruhnya terhadap kinerja karyawan PT. Dwimitra multiguna sejahtera di Kabupaten Konawe Utara Provinsi Sulawesi Tenggara. Hasil dari penelitian tersebut menyatakan bahwa terdapat hubungan dan pengaruh signifikan antara variabel gaya kepemimpinan dengan kinerja karyawan. Penelitian ini juga tidak sama dengan penelitian Aziz (2014) yang membuktikan bahwa gaya kepemimpinan memiliki pengaruh pengaruh positif signifikan terhadap kinerja karyawan PDAM Kota Padang secara parsial maupun simultan. Hal ini karena karyawan merasa apapun bentuk dorongan dan sikap atasan karyawan tetap mengupayakan untuk meningkatkan kinerja mereka. Karyawan akan menyelesaikan tugas tepat waktu karena pekerjaan yang mereka lakukan setiap hari sama dan tidak ada yang berbeda. Tetapi, dalam hal ini peneliti juga menunjukkan bahwa terdapat pengaruh antara antara kompensasi dengan kinerja karyawan, hasil penelitian yang dilakukan oleh Prasetiyo (2014) menunjukkan pengaruh positif dan signifikan antara variabel kompensasi dan kinerja karyawan. Temuan dalam penelitian ini juga menunjukkan pengaruh positif dan signifikan antara kompensasi dengan kinerja dari para karyawan. Dapat dipahami bahwa kompensasi yang semakin layak/baik maka dapat memberikan pengaruh yang kuat terhadap kepuasan kerjanya. Pengaruh positif dan signifikan antara gaya kepemimpinan terhadap kepuasan karyawan. Hasil penelitian ini sama dengan penelitian Baihaqi (2010) yang menemukan pengaruh positif dan signifikan gaya kepemimpinan terhadap kepuasan kerja karyawan diperoleh kesimpulan bahwa hipotesis ketiga dapat diterima dan terdukung. Hal ini berarti perilaku pemimpin merupakan salah satu faktor penting yang dapat mempengaruhi kepuasan kerja. Hubungan yang akrab dan saling tolong-menolong dengan teman sekerja serta dengan pemimpin adalah sangat penting dan memiliki hubungan kuat dengan kepuasan kerja, semakin baik pemimpin dalam membawahi karyawannya semakin nyaman dan puas juga para karyawan dalam melakukan pekerjaanya, begitu pula sebaliknya.

Pengaruh positif dan signifikan antara karakteristik kompensasi terhadap kepuasan kerja hasil penelitian yang dilakukan oleh Prasetiyo (2014) menunjukkan pengaruh positif dan signifikan antara variabel kompensasi dan kepuasan kerja. Temuan dalam penelitian ini juga menunjukkan pengaruh positif dan signifikan antara kompensasi dengan kepuasan kerja dari parakaryawan.

Hasil penelitian ini menunjukkan bahwa kepuasan kerja tidak berpengaruh signifikan dan positif terhadap kinerja karyawan. Hasil dalam penelitian ini tidak mendukung Primanda dan Azzuhri (2014) Pengaruh Motivasi Kerja Terhadap Kinerja Karyawan Dengan Kepuasan Kerja Sebagai Variabel Intervening Pada Kantor Pusat PT Varia Usaha Gresik yang menemukan bahwa sistem kepuasan kerja secara langsung memiliki pengaruh terhadap kinerja karyawan.

Hasil penelitian ini menunjukkan adanya pengaruh positif dan tidak signifikan tidak langsung antara gaya kepemimpinan terhadap kinerja karyawan yang dimediasi oleh kepuasan kerja. Hal tersebut berarti semakin baik gaya kepemimpinan yang dimiliki oleh perusahaan maka tidak akan 
meningkatkan kepuasan kerja dari karyawan yang pada akhirnya tidak akan berdampak secara tidak langsung meningkatkan kinerja karyawan. Penelitian ini tidak mendukung hasil Prasetiyo (2014), Pengaruh gaya kepemimpinan dan kompensasi terhadap kinerja karyawan dengan kepuasan kerja sebagai variabel intervening (Studi pada Hotel Berbintang di Yogyakarta).

Hasil penelitian ini menunjukkan adanya pengaruh positif dan tidak signifikan tidak langsung antara kompensasi terhadap kinerja karyawan yang melalui kepuasan kerja. Hal tersebut berarti semakin baik kompensasi yang diberikan kepada karyawan maka belum tentu dapat meningkatkan kepuasan kerja dari karyawan yang akan berdampak secara tidak langsung meningkatkan kinerja karyawan. Telah dijelaskan dalam hasil penelitian di atas bahwa kompensasi akan berpengaruh langsung terhadap kinerja karyawan tanpa melalui kepuasan kerja. Penelitian ini tidak mendukung hasil dari Prasetiyo (2014), Pengaruh gaya kepemimpinan dan kompensasi terhadap kinerja karyawan dengan kepuasan kerja sebagai variabel intervening (Studi pada Hotel Berbintang di Yogyakarta).

Implikasi praktis temuan-temuan ini bahwa perusahaan maupun pemimpin perlu menciptakan kondisi yang dapat meningkatkan kepuasan kerja karyawan. Dalam menciptakan kepuasan kerja hal yang perlu dibenahi oleh perusahaan dan pemimpin adalah kompensasi dan gaya kepemimpinan dari perusahaan tersebut. Demi meningkatkan kepuasan kerja dari karyawan maka pemimpin harus ada timbal balik antara atasan kebawahan maupun sebaliknya terhadap otonomi tugas yang diberikan oleh perusahaan. Otonomi tugas yang dimaksud adalah pemberian kesempatan dari karyawan untuk ikut serta dalam pengambilan keputusan. Dengan adanya otonomi tugas yang baik maka mampu menciptakan kepuasan kerja dari para karyawan dan pada akhirnya dapat meningkatkan kinerja karyawan.

Atasan perlu menciptakan kondisi yang dapat meningkatkan kepuasan kerja dari para karyawan dengan cara menyesuaikan gaya kepemimpinan yang mampu beradaptasi dengan kondisi lingkungan perusahaan tempat bekerja. Gaya kepemimpinan yang dimaksud adalah pemimpin harus mengambil inisiatif dalam bekerja sehingga dapat menjadi panutan bagi para karyawan sehingga mereka merasa puas dengan gaya kepemimpinan yang dimiliki oleh pemimpin yang kemudian berdampak pada peningkatan kinerja karyawan.

Beberapa keterbatasan dalam penelitian ini adalah sebagai berikut: Penelitian ini hanya meneliti hubungan antara variabel gaya kepemimpinan, kompensasi, kepuasan kerja dan kinerja karyawan. Penelitian ini secara birokrasi hanya mendapatkan izin penelitian pada satu biro saja yang dilakukan pada karyawan Biro Umum yang berada di kantor unit PT Varia Usaha sehingga tidak dapat digeneralisasikan terhadap seluruh karyawan PT Varia Usaha karena karyawan tersebar di Jawa Timur, Jawa Tengah dan Jawa Barat. Penelitian memiliki keterbatasan waktu karena izin yang diberikan perusahaan cukup sigkat.

\section{Simpulan}

Berdasarkan hasil pengujian hipotesis dan pembahasan, maka dapat dirumuskan beberapa kesimpulan seperti penerapan gaya kepemimpinan dari atasan yang bercirikan kepemimpinan direktif, kepemimpinan suportif, kepemimpinan partisipatif terbukti mampu mendukung peningkatan kepuasan kerja dari para karyawan. Kompensasi yang bercirikan upah dan gaji, insentif, tunjangan 
dan fasilitas terbukti mampu meningkatkan kepuasan kerja dari para karyawan. Untuk penerapan karakteristik gaya kepemimpinan dari atasan yang bercirikan kepemimpinan direktif, kepemimpinan suportif dan kepemimpinan partisipatif terbukti tidak mampu mendukung peningkatan kinerja dari para karyawan. Sedangkan kompensasi yang bercirikan pada upah dan gaji, insentif, tunjangan dan fasilitas terbukti mampu meningkatkan kinerja dari para karyawan.

Penerapan karakteristik gaya kepemimpinan dari atasan yang bercirikan kepemimpinan direktif, kepemimpinan suportif, kepemimpinan partisipatif melalui kepuasan kerja yang meliputi pekerjaan itu sendiri, kondisi lingkungan kerja, rekan kerja, gaji, atasan, promosi; ketika kesesuaian tugas pekerjaan sesuai dengan keahlian dan pengalaman karyawan; ketepatan waktu dan jumlah dalam pembayaran gaji; kepuasan kondisi di lingkungan kerja, terbukti tidak mampu meningkatkan kinerja karyawan.

Sedangkan penerapan kompensasi yang bercirikan upah dan gaji, insentif, tunjangan, fasilitas melalui kepuasan kerja yang meliputi pekerjaan itu sendiri, kondisi lingkungan kerja, rekan kerja, gaji, atasan, promosi; ketika kesesuaian tugas pekerjaan sesuai dengan keahlian dan pengalaman karyawan; ketepatan waktu dan jumlah dalam pembayaran gaji; kepuasan kondisi di lingkungan kerja terbukti tidak mampu meningkatkan kinerja karyawan.

\section{Daftar Pustaka}

Aziz, Nofriandi (2014) "Pengaruh Kepemimpinan dan Kompensasi Terhadap Kinerja Karyawan Pdam Kota Padang (Studi pada Karyawan PDAM di Padang)" Skripsi Program Studi Manajemen, Fakultas Ekonomi.
Baihaqi, Muhammad Fauzan (2010), Pengaruh Gaya Kepemimpinan Terhadap Kepuasan Kerjadan Kinerja Dengan Komitmen Organisasi Sebagai Variabel Intervening (Studi Pada PT. Yudhistira Ghalia Indonesia Area Yogyakarta). "Skripsi Universitas Diponegoro Semarang".

Dessler, Gary, 2015, Manajemen Sumber Daya Manusia, Terjemahan Diana Angelica, Salemba Empat, Jakarta.

Dharma, Agus. 2003. Dicari Kepala Sekolah yang Kompeten.

www.pendidikannetwork.co.id.

Faqih, Mansyur 2015. Suparni, Direktur Utama Semen Indonesia: Membawa Semen Indonesia Lebih Kokoh (bttp:/ / www.newsjs.com/ url.php?p $p=$ bttp:/ Lwww.republika.co.id/berita/koran/bincan g-bisnis/15/08/31/ntxvoe15-suparni direktur-utama- semen- indonesia membawa-semen- indonesia-lebib-kokoh ) Diakses pada Tanggal 27 Maret 2016. Hasibuan, Malayu S.P. (2009). Manajemen Sumber Daya Manusia (Edisi Revisi). Jakarta: Bumi Aksara.

Hendriawan (2014). Pengaruh Gaya Kepemimpinan dan Budaya Organisasi Terhadap Kinerja Karyawan pada PT. Dwimitra Multiguna Sejahtera di Kabupaten Konawe Utara Provinsi Sulawesi Tenggara. Skripsi. Universitas Hasanudin, Makassar.

Ilmawan, Mirza D. (2012). Peranan Kompensasi dan Karakteristik Kepemimpinan terhadap Kinerja Guru Melalui Kepuasan Kerja (Studi Pada Guru SMA Negeri Di Kota Malang). Thesis. Universitas Brawijaya, Malang.

Indriyatni, Lies. (2009). "Analisis Pengaruh Kompensasi dan Lingkungan Kerja Jakarta: Bumi Aksara. 
Mirza Dwinanda Ilmawan, Dwi Setia Wulandari, Fatmala Fitriani/Peran Gaya Kepeminpinan...

Juniarti, Darfina (2014). Pengaruh Kompensasi Terhadap Kinerja

Karyawan Dengan Motivasi Kerja Sebagai Variabel Mediating (Studi Kasus Pada Karyawan Perbankan Tanjung Pinang)

Lawler Ill, Edward E. 1973. Satisfaction an

Behavior dari Motivation in Work, dalam Staw, Barry M. 1991. Psychological Dimensions of Organizational Behavior. McMillan Publishing Company.

Mangkunegara, A. P. (2011). Manajemen Sumber Daya Manusia

Perusahaan.Bandung: PT Remaja Rosdakarya.

Mangkunegara, Prabu Anwar. 2001. Manajemen Sumberdaya Perusabaan.

Cetakan kedua. Rosda, Bandung.

Marihot, Hariandja T.E. (2002). Manajemen

Sumber Daya Manusia, Jakarta:

Grasindo.

Nawawi, Hadari. 2003. Manajemen

Sumberdaya Manusia untuk Bisnis yang

Kompetitif. Cetakan Ketiga. BPFE

Universitas Gajah Muda, Yogyakarta.

Noermijati. 2008. Aktualisasi Teori Herzberg,

Suatu Kajian Terbadap Kepuasan Kerja dan Kinerja Spiritual Manajer Operasional.

Disertasi. Program Pascasarjana

Fakultas Ekonomi Universitas

Brawijaya, Malang.

Notoatmodjo, Soekidjo. (2009). Pengembangan Sumber Daya Manusia. Jakarta: Rineksa

Cipta

Northouse, P. G. (2013). Leadership: Theory and practice (6th ed.). Thousand Oaks: SAGE.

Prasetyo, Sigit. (2014).'Pengaruh Gaya Kepemimpinan dan Kompensasi Terhadap Kinerja Karyawan dengan Kepuasan Kerja Sebagai Variabel Intervening (Studi pada Hotel
Berbintang di Yogyakarta)." Skripsi. Fakultas Ekonomi Universitas Negeri Yogyakarta.

Primanda, Aryo dan Misbahudin Azzuhri (2014). "Pengaruh Motivasi Kerja Terhadap Kinerja Karyawan Dengan Kepuasan Kerja Sebagai Variabel Intervening Pada Kantor Pusat PT Varia Usaha Gresik" Skripsi Jurusan Manajemen Fakultas Ekonomi dan Bisnis Universitas Brawijaya.

Rivai, Veithzal., Mansyur Ramly, Thoby Muthis dan Willy Arafah. 2014. Manajemen Sumber Daya Manusia untuk Perusahaan: Dari Teori ke Praktik. PT. Rajagrafindo Persada, Jakarta.

Sanusi, Anwar. 2003. Metode Penelitian Praktis untuk Ilmu Sosial dan Ekonomi. Cetakan pertama. Malang: Buntara Media.

Simamora, Henry. 2004. Manajemen Sumber Daya Manusia. Yogyakarta: STIEYKPN terhadap Produktivitas Kerja Perawat dengan Kepuasan Kerja sebagai Variabel Mediasi." Jurnal Ekonomi Manajemen Akuntansi, No. 26,Th.XVI, pp. 117127.

Simamora, Henry. 2006. Manajemen Sumber Daya Manusia. Edisi 3. BP STIE YKPN, Yogyakarta.

Singarimbun, Masri dan Sofian Effendi. 2006. Metode Penelitian Survey. Edisi Revisi. LP3ES, Jakarta.

Yulk, Gary (2015). Kepemimpinan dalam Organisasi. Edisi Ketujuh. Alih bahasa: Ati Cahyani. PT Indeks Permata Puri Media. Jakarta Barat. 